\title{
KECERDASAN EMOSIONAL DAN MOTIVASI BELAJAR DENGAN HASIL BELAJAR MATA PELAJARAN DASAR LISTRIK DAN ELEKTRONIKA DI SMKN 34 JAKARTA
}

${ }^{1}$ Intan Agustina Prabowo, ${ }^{2}$ Suyitno, ${ }^{3}$ Daryanto

${ }^{1,2,3}$ S1 Pendidikan Teknik Elektro, Fakultas Teknik, Universitas Negeri Jakarta

1,2,3Email : intanaggst@gmail.com; suyitno@unj.ac.id; daryanto@unj.ac.id

\begin{abstract}
The purpose of this study is to know the correlation between emotional intelligence and learn motivaton by theirself and in group with result of learn with a sample of 60 people using the expost facto research method. Research data were processed using descriptive and inferential statistics. From the analysis of the data obtained by the correlation coefficient ry $x_{1 \text { computed }}=0.703 ;$ ry $x_{2 \text { computed }}=0.676 ; r x_{1} x_{2 c o m p u t e d}=0.875 ; r y x_{1} x_{2}=0.714$. The conclusion of this study, there is a positive and significant relationship between the emotional intelligence and learn motivation with result of learn.

Keywords : Emotional Intelligence, Learn Motivation, Result of Learn
\end{abstract}

\begin{abstract}
Abstrak
Tujuan penelitian ini adalah untuk mengetahui hubungan antara kecerdasan emosional dan motivasi belajar baik secara sendiri-sendiri maupun bersama-sama dengan hasil belajar mata pelajaran Dasar Listrik dan Elektronika dengan jumlah sampel 60 orang menggunakan metode penelitian expost facto. Data hasil penelitian diolah dengan statistika deskriptif dan inferensial. Dari analisis data diperoleh nilai koefisien korelasi ryx ${ }_{1}$ hitung $=0,703$; ryx $_{2}$ hitung $=0,676 ; \mathrm{rx}_{1} \mathrm{x}_{2}$ hitung $=0,875 ; \operatorname{ryx}_{1} \mathrm{x}_{2}=0,714$. Kesimpulan dari penelitian ini yaitu terdapat hubungan yang positif dan signifikan antara kecerdasan emosional dan motivasi belajar dengan hasil belajar.

Kata Kunci : Kecerdasan Emosional, Motivasi Belajar,Hasil Belajar
\end{abstract}

\section{PENDAHULUAN}

Hasil belajar siswa tercermin dari hasil evaluasi, hasil ulangan dan hasil ujian praktek yang dilakukan siswa, didalamnya mencakup aspek kognitif (pemahaman dan inteklektual), afektif (sikap dan nilai-nilai) dan psikomotor (keterampilan) setelah siswa menerima pembelajaran. Siswa diberikan perlakuan yang sama dalam kegiatan pembelajaran, namun hasil belajar yang diperoleh siswa berbeda-beda. Kebanyakan siswa mengalami masalah belajar yang berakibat pada nilai ulangan dibawah KKM.

Siswa seringkali tidak dapat mengontrol dan mengendalikan dirinya dalam belajar, terlihat dengan seringnya siswa tidur dan mengobrol dalam kelas. Sebagian besar siswa juga terlihat kurang antusias dan berpartisipasi dalam pembelajaran. Untuk mengetahui permasalahan tersebut, perlu ditelusuri beberapa faktor yang mempengaruhi hasil belajar siswa.

${ }^{[1]}$ Menurut Dalyono (2010) berhasil atau tidaknya seseorang dalam belajar disebabkan dua faktor yaitu faktor internal (berasal dari dalam diri orang yang belajar) meliputi ; kesehatan, intelegensi dan bakat, minat dan motivasi dan cara belajar atau gaya belajar) dan factor eksternal (berasal dari luar diri orang yang belajar) yang meliputi ; keluarga, sekolah, masyarakat dan lingkungan sekolah. Salah satu faktor internal yang mempengaruhi hasil belajar adalah intelegensi/ kecerdasan, salah satu bentuk kecerdasan adalah kecerdasan mengelola emosi atau kecerdasan emosional. ${ }^{[2]}$ Menurut Goleman (1996:42) kecerdasan emosional adalah kemampuan untuk mengenali kita sendiri dan perasaan orang lain, kemampuan memotivasi diri sendiri, dan kemampuan mengelola emosi dengan baik dalam diri dan hubungan dengan orang lain. Seseorang dengan kecerdasan emosional yang tinggi dapat mengenali, mengekspresikan dan mengelola emosinya dengan tindakan konstuktif yang mengacu pada produktifitas. Siswa yang memiliki kecerdasan emosional yang tinggi memiliki kemampuan untuk memotivasi diri dalam belajar dan bertahan menghadapi kesulitan-kesulitan belajar.

Selain itu penentu berhasilnya suatu pembelajaran yang tidak kalah penting yaitu motivasi belajar. Kegiatan belajar mengajar akan lebih mudah dilakukan jika peserta didik memiliki kemauan dari dalam dirinya sendiri untuk belajar. Jika motivasi belajar sudah tertanam maka siswa akan terpacu untuk mencapai tujuan belajar. Motivasi dalam belajar adalah faktor yang penting karena hal tersebut merupakan keadaan yang mendorong siswa untuk melakukan kegiatan belajar. ${ }^{[3]}$ Sardiman (2006:89) menyatakan bahwa dengan 
terangsangnya motivasi siswa maka siswa-siswa akan lebih giat sehingga dengan demikian diharapkan prestasi siswa akan menjadi lebih baik. Oleh karena itu didalam proses pembelajaran siswa diharapkan memiliki motivasi belajar. Motivasi dalam belajar adalah bagaimana cara mengatur agar belajar dapat ditingkatkan. Menurut pengamatan di lapangan dan diskusi dengan guru, peneliti menyimpulkan bahwa hasil belajar di kelas X SMKN 34 Jakarta kurang memuaskan, hal ini mungkin diakibatkan karena faktor kecerdasan emosional dan motivasi siswa dalam belajar dan sehingga ia tidak dapat mengatur proses belajar dirinya. Berdasarkan hal tersebut maka dilakukan penelitian tentang "Hubungan Kecerdasan Emosional dan Motivasi Belajar dengan Hasil Belajar Mata Pelajaran Dasar Listrik dan Elektronika di SMKN 34 Jakarta”.

\section{METODE}

Jenis desain penelitian ini termasuk dalam penelitian deskriptif korelatif. ${ }^{[4]}$ Menurut Arikunto (2010: 3) penelitian yang dilakukan untuk mengetahui tingkat hubungan antara dua variabel atau lebih, tanpa melakukan perubahan, tambahan atau manipulasi terhadap data yang sudah ada. ${ }^{[5]}$ Penelitian ini menggunakan pendekatan kuantitatif, yaitu dengan pengumpulan data menggunakan instrumen penelitian, analisis data bersifat kuantitatif/statistik dengan tujuan untuk menguji hipotesis yang telah ditetapkan (Sugiyono, 2011: 14. Penelitian ini ditujukan untuk menguji hipotesis yang telah diajukan dengan cara mencari besarnya hubungan variabel bebas terhadap variabel terikat. Paradigma atau model hubungan antara variabel $\mathrm{X}_{1}$ dan $\mathrm{X}_{2}$ dan $\mathrm{Y}$ dapat digambarkan sebagai berikut:

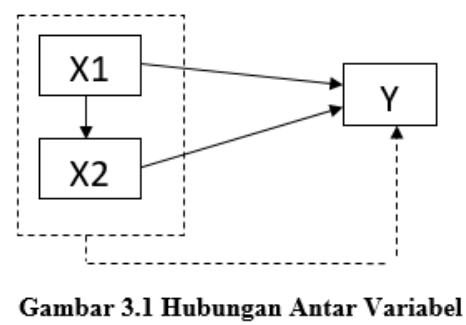

$\mathrm{X}_{1}$ : Kecerdasan Emosional (variabel bebas)

$\mathrm{X}_{2}$ : Motivasi Belajar (variabel bebas)

Y : Hasil Belajar Dasar Listrik dan Elektronika (variabel terikat)
Populasi merupakan wilayah generalisasi yang terdiri atas objek/ subjek yang mempunyai kualitas dan karakteristik tertentu yang ditetapkan oleh peneliti untuk dipelajari dan kemudian ditarik kesimpulannya (Sugiyono, 2010: 117). Populasi dalam penelitian ini adalah siswa program keahlian TIPTL di SMK Negeri 34 Jakarta sebanyak 175 orang dan diambil 60 orang kelas $\mathrm{X}$ sebagai sampel. Metode pengambilan data untuk variabel kecerdasan emosional dan motivasi belajar menggunakan kuesioner model angket dengan Skala Likert, sedangkan untuk variabel hasil belajar menggunakan metode dokumentasi berupa nilai UTS semester 1Teknik analisis data yang digunakan dalam penelitian ini adalah statistik deskriptif.. Pengujian hipotesis dalam penelitian ini menggunakan nilai $\alpha=0,05$, namun sebelum melakukan uji hipotesis, terlebih dahulu dilakukan uji normalitas menggunakan Chi Kuadrat dan linearitas. Lalu setelah melakukan uji normalitas dan uji lilearitas maka dilakukan uji hipotesis menggunakan analisis korelasi Pearson's Product Moment., Uji t, dan uji F.

\section{HASIL DAN PEMBAHASAN Hasil Belajar}

Berikut adalah distribusi frekuensi nilai hasil belajar yang dapat dilihat pada Tabel 1

Tabel 1. Distribusi Frekuensi Data Hasil Belajar

\begin{tabular}{lccc}
\hline No & $\begin{array}{c}\text { Kelas } \\
\text { Interval }\end{array}$ & Tepi Kelas & $\mathrm{f}$ \\
\hline 1. & $55-59$ & $54,5-59,5$ & 1 \\
2. & $60-64$ & $59,5-64,5$ & 4 \\
3. & $65-69$ & $64,5-69,5$ & 7 \\
4. & $70-74$ & $69,5-74,5$ & 9 \\
5. & $75-79$ & $74,5-79,5$ & 17 \\
6. & $80-84$ & $79,5-84,5$ & 11 \\
7. & $85-89$ & $84,5-89,5$ & 11 \\
\hline \multicolumn{5}{c}{ Jumlah } & 60 \\
\hline
\end{tabular}

Berdasarkan tabel 1, dapat diketahui bahwa variabel hasil belajar memiliki frekuensi tertinggi yaitu sebanyak 17 siswa yang memiliki nilai pada rentang 75-79 dan memiliki frekuensi 
relatif sebesar $28 \%$ dari total sampel, sedangkan frekuensi terendah yakni sebanyak 1 siswa yang terletak pada interval kelas ke 1 (satu) yakni antara 55-59 dan memiliki frekuensi relatif sebesar $2 \%$ dari total sampel. Kemudian hasil lainnya yaitu sebanyak 4 siswa memiliki nilai pada rentang 60-64 sebesar 7\%, lalu 7 siswa yang memiliki nilai pada rentang 65-69 sebesar $12 \%$, lalu 9 siswa yang memiliki rentang nilai $70-74$ sebesar $15 \%$, lalu 11 siswa memiliki rentang nilai $80-84$ sebesar $18 \%$ dan 11 siswa memiliki rentang nilai 85-89 sebesar $18 \%$.

\section{Kecerdasan Emosional}

Berikut adalah distribusi frekuensi nilai kecerdasan emosional yang dapat dilihat pada Tabel 2

\section{Tabel 2. Distribusi Frekuensi Data Kecerdasan Emosional}

\begin{tabular}{cccc}
\hline No & $\begin{array}{c}\text { Kelas } \\
\text { Interval }\end{array}$ & Tepi Kelas & F \\
\hline 1. & $94-99$ & $93,5-99,5$ & 2 \\
2. & $100-105$ & $99,5-105,5$ & 4 \\
3. & $106-111$ & $105,5-111,5$ & 16 \\
4. & $112-117$ & $111,5-117,5$ & 21 \\
5. & $118-123$ & $117,5-123,5$ & 9 \\
6. & $124-129$ & $123,5-129,5$ & 4 \\
7. & $130-135$ & $129,5-135,5$ & 4 \\
\hline \multicolumn{4}{c}{ Jumlah } \\
\hline
\end{tabular}

Berdasarkan tabel 2, dapat diketahui bahwa variabel kecerdasan emosional memiliki frekuensi tertinggi yaitu sebanyak 21 siswa pada rentang 112-117 dan memiliki frekuensi relatif sebesar $35 \%$ dari total sampel, sedangkan frekuensi terendah yakni sebanyak 2 siswa yang terletak pada interval kelas ke 1 (satu) yakni antara 94-99 dan memiliki frekuensi relatif sebesar 3\% dari total sampel. Kemudian hasil lainnya yaitu rentang 130-135 memiliki frekuensi 4 siswa dengan frekuensi relatif sebesar 7\%, lalu pada rentang 100-105 memiliki frekuensi 4 siswa dengan frekuensi relatif sebesar 7\%, lalu rentang 106-111 memiliki frekuensi 16 siswa dengan frekuensi relatif sebesar $27 \%$, lalu 9 siswa memiliki rentang nilai
118-123 dengan frekuensi relatif sebesar $15 \%$ dan 4 siswa memiliki rentang nilai 124-129 dengan frekuensi relatif sebesar $7 \%$.

\section{Motivasi Belajar}

Berikut adalah distribusi frekuensi motivasi belajar yang dapat dilihat pada tabel 3

\begin{tabular}{|c|c|c|c|}
\hline \multicolumn{4}{|c|}{ Belajar } \\
\hline No & $\begin{array}{c}\text { Kelas } \\
\text { Interval }\end{array}$ & Tepi Kelas & $\mathrm{F}$ \\
\hline 1. & $80-85$ & $79,585,5$ & 5 \\
\hline 2. & $86-91$ & $85,5-91,5$ & 11 \\
\hline 3. & 92-97 & $91,5-97,5$ & 13 \\
\hline 4. & $98-103$ & $97,5-103,5$ & 14 \\
\hline 5. & 104-109 & $103,5-109,5$ & 11 \\
\hline 6. & $110-115$ & $109,5-115,5$ & 4 \\
\hline 7. & $116-121$ & $115,5-121,5$ & 2 \\
\hline & & & 60 \\
\hline
\end{tabular}

Berdasarkan tabel 3, dapat diketahui bahwa variabel motivasi belajar memiliki frekuensi tertinggi yaitu sebesar 98-103 memiliki frekuensi sebanyak 14 siswa dan frekuensi relatif sebesar $23 \%$, sedangkan frekuensi terendah yang terletak pada interval kelas ke 7 (tujuh) yakni antara 116-121 memiliki frekuensi sebanyak 1 siswa dengan frekuensi relatif sebesar 3\%.

Kemudian hasil lainnya yaitu pada rentang 80-85 memiliki frekuensi 5 siswa dengan frekuensi relatif sebesar $8 \%$, lalu pada rentang 86-91 memiliki frekuensi 11 siswa dengan frekuensi relatif sebesar $18 \%$, lalu pada rentang 92-97 memiliki frekuensi 13 siswa dengan frekuensi relatif sebesar $22 \%$, lalu rentang 104-109 memiliki frekuensi 11 siswa dengan frekuensi relatif sebesar $18 \%$ dan pada rentang 110-115 memiliki frekuensi 4 siswa dengan frekuensi relatif sebesar $7 \%$.

\section{Uji Normalitas}


Berikut adalah perhitungan uji normalitas kecerdasan emosional, motivasi belajar dan hasil belajar yang dapat dilihat pada Tabel 4 .

Tabel 4. Uji Normalitas Kecerdasan Emosional, Motivasi Belajar dan Hasil Belajar

\begin{tabular}{ccccc}
\hline $\begin{array}{c}\text { Uji } \\
\text { Normalitas }\end{array}$ & Dk & $\chi^{2}$ & $\begin{array}{c}\chi^{2} \\
\text { hitung }\end{array}$ & Ket \\
\hline $\begin{array}{c}\text { Kecerdasan } \\
\text { Emosional }\end{array}$ & 6 & 12,59 & 7,095 & Normal \\
$\begin{array}{c}\text { Motivasi } \\
\text { Belajar }\end{array}$ & 6 & 12,59 & 1,078 & Normal \\
Hasil Belajar & 6 & 12,59 & 4,780 & Normal
\end{tabular}

Pada tabel 4, untuk variabel kecerdasan emosional $\chi^{2}$ hitung $=7,095$, sedangkan $\chi_{\text {tabel }}^{2}=$ 12,59 , untuk $\alpha=0,05 \mathrm{dan} \mathrm{dk}=6$. Karena $\chi^{2}$ hitung $\leq \chi_{\text {tabel }}^{2}$ maka dapat disimpulkan bahwa penyebaran data pada variabel kecerdasan emosional berdistribusi normal. Lalu untuk variabel motivasi belajar $\chi^{2}$ hitung $=1,078$, sedangkan $\chi_{\text {tabel }}^{2}=12,59$, untuk $\alpha=0,05$ dan dk $=6$. Karena $\chi^{2}$ hitung $\leq \chi_{\text {tabel }}^{2}$ maka dapat disimpulkan bahwa penyebaran data pada variabel motivasi belajar berdistribusi normal dan untuk variabel hasil belajar dasar listrik dan elektronika $\chi_{\text {hitung }}^{2}=4,780$, sedangkan $\chi_{\text {tabel }}^{2}=$ 12,59 , untuk $\alpha=0,05 \mathrm{dan} \mathrm{dk}=6$. Karena $\chi^{2}$ hitung $\leq \chi_{\text {tabel }}^{2}$ maka dapat disimpulkan bahwa penyebaran data pada variabel hasil belajar dasar listrik dan elektronika berdistribusi normal.

\section{Uji Linieritas}

Berikut adalah perhitungan uji linieritas kecerdasan emosional dengan hasil belajar dapat dilihat pada Tabel 5 .

Tabel 5. Uji Linieritas Kecerdasan Emosional dengan Hasil Belajar

\begin{tabular}{|c|c|c|c|c|c|}
\hline $\begin{array}{c}\text { Uji } \\
\text { Linieritas }\end{array}$ & n & Dk & $\begin{array}{c}\mathbf{F} \\
\text { hitung }\end{array}$ & $\begin{array}{c}\mathbf{F} \\
\text { tabel }\end{array}$ & Ket \\
\hline $\begin{array}{c}\text { Kecerdasa } \\
n\end{array}$ & & & & & \\
\hline $\begin{array}{c}\text { Emosional } \\
\text { dengan } \\
\text { Hasil } \\
\text { Belajar }\end{array}$ & 60 & 31 & 0,71 & 1,89 & $\begin{array}{c}\text { Linie } \\
r\end{array}$ \\
\hline
\end{tabular}

Berdasarkan hasil analisis varians (Anava) pada tabel 5, diketahui nilai variabel kecerdasan emosional dan hasil belajar dasar listrik dan elektronika yaitu $F_{\text {hitung }}=0,712$ dengan derajat kebebasan (dk) pembilang sebesar $27 \mathrm{dan} \mathrm{dk}$ penyebut sebesar 31 dan taraf signifikansi $\alpha=$ $5 \%$, maka diperoleh $\mathrm{F}_{\text {tabel }}=1,89$. Dilihat dari kriteria pengujian yang digunakan, maka diperoleh hasil pengujian hipotesis tersebut menunjukkan Fhitung $\leq$ Ftabel maka $\mathrm{H} 0$ diterima yang berarti terdapat persamaan linear antara variabel kecerdasan emosional dan hasil belajar dasar listrik dan elektronika.

Selanjutnya adalah perhitungan uji linieritas motivasi belajar dengan hasil belajar yang dapat dilihat pada Tabel 6 .

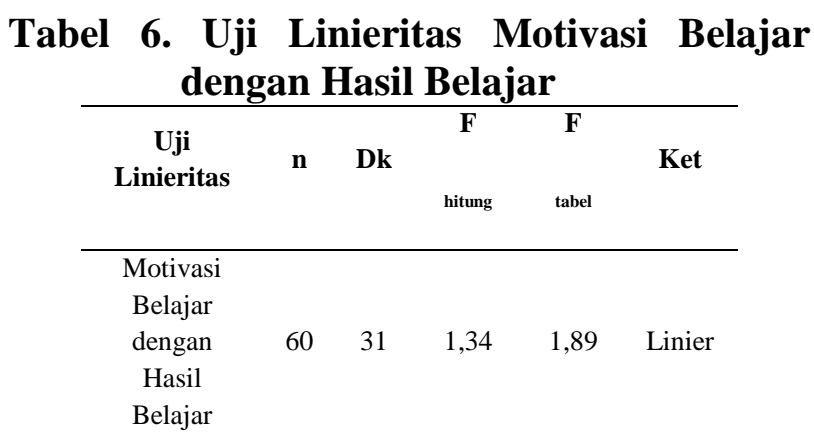

Berdasarkan hasil analisis varians (Anava) pada tabel 6, diketahui nilai variabel motivasi belajar dan hasil belajar dasar listrik dan elektronika diperoleh Fhitung $=1,349$ dengan derajat kebebasan (dk) pembilang sebesar 27 dan dk penyebut sebesar 31 dan taraf signifikansi $\alpha=5 \%$, maka diperoleh Ftabel $=$ 1,89. Dapat dilihat dari kriteria pengujian yang digunakan, maka diperoleh hasil pengujian hipotesis tersebut Fhitung $\leq$ Ftabel maka H0 diterima yang berarti terdapat persamaan linier antara variabel motivasi belajar dan hasil belajar dasar listrik dan elektronika.

\section{Uji Hipotesis}

\section{Hubungan antara Kecerdasan Emosional dengan Hasil Belajar}

Berikut adalah perhitungan uji Hipotesis korelasi pearson product moment kecerdasan emosional dengan hasil belajar dapat dilihat 
pada Tabel 7 dan Tabel 8 untuk Uji Signifikansi Korelasi.

Tabel 7. Uji Korelasi Pearson Product

\begin{tabular}{ccccc} 
Moment & & & \\
\hline dk & a & $\mathbf{r}$ & $\mathbf{r}$ & Ket \\
& & hitung & tabel & \\
\hline 60 & 0,05 & 0,699 & 0,254 & Ha \\
& & & & Diterima
\end{tabular}

Tabel 8. Uji Signifikansi Korelasi (Uji t)

\begin{tabular}{ccccc}
\hline dk & a & $\begin{array}{c}\text { t } \\
\text { hitung }\end{array}$ & $\begin{array}{c}\text { tabel } \\
\text { tat }\end{array}$ & \\
\hline 60 & 0,05 & 7,44 & 2,000 & $\begin{array}{c}\text { Ha } \\
\text { Diterima }\end{array}$
\end{tabular}

\section{Hubungan antara Motivasi Belajar dengan Hasil Belajar}

Berikut adalah perhitungan uji Hipotesis korelasi pearson product moment motivasi belajar dengan hasil belajar dapat dilihat pada Tabel 9 dan Tabel 10 untuk Uji Signifikansi Korelasi.

Tabel 9. Uji Korelasi Pearson Product

\begin{tabular}{ccccc} 
Moment & & & \\
\hline dk & a & $\mathbf{r}$ & $\mathbf{r}$ & Ket \\
& & hitung & tabel & \\
\hline 60 & 0,05 & 0,672 & 0,254 & Ha \\
& & & & Diterima
\end{tabular}

Tabel 10. Uji Signifikansi Korelasi (Uji t)

\begin{tabular}{ccccc}
\hline dk & a & $\begin{array}{c}\text { t } \\
\text { hitung }\end{array}$ & $\begin{array}{c}\text { t } \\
\text { tabel }\end{array}$ & Ket \\
& & & & \\
\hline 60 & 0,05 & 6,910 & 2,000 & Ha \\
& & & & Diterima
\end{tabular}

Hubungan antara Kecerdasan Emosional dengan Motivasi Belajar
Selanjutnya adalah perhitungan uji Hipotesis korelasi pearson product moment kecerdasan emosional dengan motivasi belajar dapat dilihat pada Tabel 11 dan Tabel 12 untuk Uji Signifikansi Korelasi.

Tabel 11. Uji Korelasi Pearson Product

\begin{tabular}{|c|c|c|c|c|}
\hline \multicolumn{5}{|c|}{ Moment } \\
\hline dk & $\mathbf{a}$ & $\begin{array}{c}\mathbf{r} \\
\text { hitung }\end{array}$ & $\begin{array}{c}r \\
\text { tabel }\end{array}$ & Ket \\
\hline 60 & 0,05 & 0,875 & 0,254 & $\mathrm{Ha}$ \\
\hline
\end{tabular}

Tabel 12. Uji Signifikansi Korelasi (Uji t)

\begin{tabular}{ccccc}
\hline dk & $\mathbf{a}$ & $\begin{array}{c}\mathbf{t} \\
\text { hitung }\end{array}$ & $\begin{array}{c}\text { tabel } \\
\text { tat }\end{array}$ & \\
\hline 60 & 0,05 & 13,764 & 2,000 & $\mathrm{Ha}$ \\
\hline
\end{tabular}

Selanjutnya adalah perhitungan uji Hipotesis korelasi pearson product moment kecerdasan emosional dan motivasi belajar dengan hasil belajar dapat dilihat pada Tabel 13 dan Tabel 14 untuk Uji Signifikansi Korelasi.

Tabel 13. Uji Korelasi Pearson Product

\begin{tabular}{ccccc}
\multicolumn{3}{c}{ Moment } & & \\
\hline dk & a & $\begin{array}{c}\text { r } \\
\text { hitung }\end{array}$ & $\begin{array}{c}\text { Ket } \\
\text { tabel }\end{array}$ & \\
& & & & \\
\hline 60 & 0,05 & 0,710 & 0,254 & Ha \\
& & & & Diterima
\end{tabular}

Tabel 14. Uji Signifikansi Korelasi (Uji F)

\begin{tabular}{ccccc}
\hline dk & a & $\begin{array}{c}\text { F } \\
\text { hitung }\end{array}$ & $\begin{array}{c}\text { F } \\
\text { tabel }\end{array}$ & Ket \\
& & & & \\
\hline 60 & 0,05 & 28,971 & 3,15 & Ha \\
& & & & Diterima
\end{tabular}




\section{Kesimpulan}

Dari penelitian dan pengolahan data yang sudah dilakukan, menyatakan bahwa terdapat hubungan antara kecerdasan emosional dengan hasil belajar dasar listrik dan elektronika siswa kelas X TITL SMK Negeri 34 Jakarta. Berdasarkan hasil perhitungan koefisien korelasi product moment dan uji-t menunjukkan nilai $r_{\mathrm{yx} 1}=0,699$ yang termasuk dalam kategori tinggi pada tabel korelasi dan thitung $=7,444$ nilai ini lebih besar dari $t_{\text {tabel }}=2,000$ yang berarti signifikan. Maka dapat dikatakan bahwa kedua variabel tersebut mempunyai hubungan positif dan signifikan.

Selanjutnya dari penelitian dan pengolahan data yang sudah dilakukan, menyatakan bahwa terdapat hubungan antara motivasi belajar dengan hasil belajar dasar listrik dan elektronika siswa kelas X TITL SMK Negeri 34 Jakarta. Berdasarkan hasil perhitungan koefisien korelasi product moment dan uji-t menunjukkan nilai $\mathrm{r}_{\mathrm{yx} 2}=0,672$ yang termasuk dalam kategori tinggi pada tabel korelasi dan $t_{\text {hitung }}=6,910$ nilai ini lebih besar dari $t_{\text {tabel }}=2,000$ yang berarti signifikan. Maka dapat dikatakan bahwa kedua variabel tersebut mempunyai hubungan positif dan signifikan.

Lalu dari penelitian dan pengolahan data yang sudah dilakukan, menyatakan bahwa terdapat hubungan antara kecerdasan emosional dengan motivasi belajar siswa kelas X TITL SMK Negeri 34 Jakarta. Berdasarkan hasil perhitungan koefisien korelasi product moment dan uji-t menunjukkan nilai $r_{x 1,2}=0,875$ yang termasuk dalam kategori tinggi pada tabel korelasi dan $t_{\text {hitung }}=13,764$ nilai ini lebih besar dari $t_{\text {tabel }}=2,000$ ysng berarti signifikan. Maka dapat dikatakan bahwa kedua variabel tersebut mempunyai hubungan positif dan signifikan.

Selamjutnya dari penelitian dan pengolahan data yang sudah dilakukan, menyatakan bahwa terdapat hubungan antara kecerdasan emosional dan motivasi belajar dengan hasil belajar dasar listrik dan elektronika siswa kelas X TITL SMK Negeri 34 Jakarta. Berdasarkan hasil perhitungan koefisien korelasi product moment dan uji-F menunjukkan nilai $\mathrm{r}_{\mathrm{yx} 1,2}=0,710$ yang termasuk dalam kategori tinggi pada tabel korelasi dan $F_{\text {hitung }}=28,971$ nilai ini lebih besar dari $F_{\text {tabel }}=3,15$ yang berarti signifikan. Maka dapat dikatakan bahwa variabel bebas secara bersama-sama mempunyai hubungan yang positif dan signifikan dengan hasil belajar dasar listrik dan elektronika.

\section{Saran}

a. Bagi siswa

Peneliti menyarankan untuk berusaha memahami dan mengendalikan emosi, perbanyak berinteraksi dengan orang lain agar dapat belajar memahami emosi orang lain dan dapat membina hubungan dengan baik dengan orang lain. Dengan kecerdasan emosional yang baik maka akan mempengaruhi pengambilan keputusan dan penerimaan belajar dan akhirnya berpengaruh pada hasil belajar

b. Bagi orang tua

Luangkan waktu untuk mendengarkan keinginan anak, ajak anak berdiskusi dalam mengambil keputusan agar anak tahu betul alas an pengambilan suatu keputusan. Berikan motivasi-motivasi dan berikan contoh cara mnegelola emosi dengan baik.

c. Bagi sekolah

Agar terus memberikan bimbingan kepada siswanya untuk dapat mengelola dan menyalurkan emosinya secara positif, bertanggung jawab atas apa yang dilakukan, dan memiliki motivasi belajar yang tinggi.

d. Bagi penelitian selanjutnya

Sebagai bahan masukan dan pengetahuan untuk melakukan penelitian sejenis diharapkan mampu menemukan variabel lain yang lebih luas dan variatif sehingga dapat menambah hasil-hasil penelitian.

DAFTAR PUSTAKA

[1] Dalyono. 2010. Psikologi Pendidikan. Jakarta: Rineka Cipta.

[2] Goleman, Daniel. 1996. Emotional Intelligence. Jakarta :PT. Gramedia Pustaka Utama.

[3] Sardiman. 2006. Interaksi \& Motivasi Belajar Mengajar. Jakarta: Rajawali Pers.

[4] Arikunto, Suharsimi. 2010. Prosedur Penelitian Suatu Pendekatan Publik. Jakarta: Bumi Aksara.

${ }^{[5]}$ Pendidikan. Bandung : Remaja Rosdakarya. Sugiyono. (2012).Metode Penelitian Kuantitatif Kualitatif dan $R \& D$. Bandung: Alfabeta. 